\title{
ANALISIS HUKUM KONTRAK SYARIAH TERHADAP TRANSAKSI KEPEMILIKAN RUMAH DENGAN TANAH BERSERTIFIKAT HAK GUNA BANGUNAN DI PT. SUCI GRIYA PERSADA
}

\author{
Robiatul Adhawiyah \\ Parman Komarudin \\ Muhammad Rifqi Hidayat \\ Fakultas Studi Islam Universitas Islam Kalimantan Muhammad Arsyad al-Banjari Banjarmasin
}

\begin{abstract}
This research was conducted with the aim of analyzing the practice of buying and selling of houses with the bulding rights land (Hak Guna Bangunan - HGB) at PT. Suci Griya Perdana through the perspective of sharia contract law. This research is a qualitative type that uses a sociological juridical approach. Data is processed using triangulation techniques based on interviews with companies and buyers, direct observation of company offices and land as the object of transaction, and documents in the form of deeds of sale and purchase of the land. The processed data is then analyzed using the perspective of sharia contract law, especially through the buying and selling theory, and ownership theory in Islamic law as the qiyas basis for the practice of selling houses with this HGB lands status. The results of the analysis show that transactions like this are not permitted if the mechanism is fully implemented with a sale and purchase agreement. Unless the developer sells it separately, that the house with a sale and purchase contract and the land with a lease agreement, then the transaction can be justified.
\end{abstract}

\begin{abstract}
Abstrak: Riset ini dilakukan dengan tujuan untuk menganalisa praktik transaksi jual-beli rumah dengan tanah bersertifikat Hak Guna Bangunan (HGB) di PT. Suci Griya Perdana melalui perspektif hukum kontrak syariah. Penelitian ini merupakan jenis kualitatif yang menggunakan pendekatan Yuridis Sosiologis. Data diolah dengan menggunakan teknik triangulasi berdasarkan wawancara kepada pihak perusahaan dan pembeli, observasi langsung ke kantor perusahaan dan tanah yang menjadi objek jual-beli, serta dokumen berupa akta jual beli tanah tersebut. Data yang telah diolah kemudian dianalisa menggunakan perspektif hukum kontrak syariah, khususnya melalui teori jual-beli dan teori kepemilikan dalam hukum Islam sebagai dasar qiyas terhadap praktek penjualan rumah dengan tanah berstatus HGB ini. Hasil analisis menunjukkan bahwa transaksi seperti ini tidak diperkenankan jika mekanismenya dilakukan sepenuhnya dengan akad jual beli. Terkecuali developer menjualnya secara terpisah, yaitu rumah dengan akad jual beli dan tanah dengan akad sewa, maka transaksi tersebut dapat dibenarkan.
\end{abstract}

Kata Kunci: Hak Guna Bangunan; Perumahan.

\section{Pendahuluan}

Rumah merupakan satu dari tiga serangkai kebutuhan dasar manusia yang terdiri dari sandang, pangan, dan papan. ${ }^{1}$ Media perumahan menjadi sarana bagi manusia guna melakukan berbagai macam aktifitas hidup dan sarana untuk memberikan perlindungan utama terhadap adanya gangguan-gangguan eksternal, baik terhadap kondisi iklim ataupun gangguan lainnya.

Saat ini konsep perumahan telah mengalami pergeseran, tidak hanya sebagai kebutuhan dasar saja, ataupun sebagai media yang memberikan perlindungan, namun perumahan telah menjadi gaya hidup (life style), ${ }^{2}$ memberikan kenyamanan dan menunjukkan karakteristik atau jati diri, yang merupakan salah satu pola pengembangan diri serta sarana private, sebagaimana dibutuhkan pada masyarakat global.

\footnotetext{
1 Toha Muhaimin, "Mengukur Kualitas Hidup Anak," Kesmas: National Public Health Journal 5, no. 2 (2010): 51.

2 Sari Listyorini, "Analisis Faktor-Faktor Gaya Hidup dan Pengaruhnya Terhadap Pembelian Rumah Sehat
}

Berbicara mengenai perumahan, maka tidak terlepas dengan masalah pertanahan. Kedua komponen tersebut tidak dapat dipisahkan. Jika pada masa lalu seseorang dapat memindahkan rumah dari suatu lahan dengan mudah, namun pada jaman sekarang rumah dan tanah telah menjadi satu kesatuan yang tak terpisahkan. Artinya, jual beli benda-benda tersebut perlu adanya kepastian dan perlindungan hukumnya.

Idealnya, suatu rumah harus dijual beserta tanahnya dalam bentuk hak milik penuh. Konsep hak milik secara yuridis diatur dalam Pasal 20 ayat (1) \& (2) Undang-Undang tentang Peraturan Dasar Pokok-Pokok Agraria (UUPA) yang menegaskan bahwa, hak milik adalah hak turun temurun, terkuat dan terpenuh yang dapat dipunyai orang atas tanah dengan mengingat ketentuan dalam Pasal 6 UUPA,

Sederhana (Studi pada Pelanggan Perumahan Puri Dinar Mas PT. Ajisaka di Semarang)," Jurnal Administrasi Bisnis 1, no. 1 (2012): 12. 
dan hak ini dapat beralih serta dialihkan pada pihak lain. ${ }^{3}$

Hanya saja beberapa Developer menjual perumahan dengan tanah yang berstatus Hak Guna Bangunan (HGB), salah satunya yaitu PT. Suci Griya Persada. Perlu diketahui bahwa HGB pada hakikatnya bukanlah hak milik atas sebuah lahan, pemilik hanya memiliki hak untuk memanfaatkan bangunan yang berdiri di suatu lahan milik negara. Sederhananya, apabila suatu properti dibeli dengan status sertifikat HGB, maka pembeli hanya memiliki bangunannya saja, sedangkan tanahnya berstatus dikuasai oleh negara, sehingga diperlukan perpanjangan atas hak penggunaan lahan, dan hanya bisa dilakukan sebanyak 2 (dua) kali perpanjangan. Hal ini sebagaimana disebutkan dalam definisi HGB dalam Pasal 35 UUPA yaitu hak untuk mendirikan dan mempunyai bangunan atas tanah yang bukan miliknya sendiri, dengan jangka waktu paling lama 30 tahun dan dapat diperpanjang untuk jangka waktu paling lama 20 tahun. ${ }^{4}$

Uniknya, HGB ini ditawarkan kepada pembeli dalam bentuk transaksi jual-beli. Sedangkan dalam hukum Islam, akad jual beli mengakibatkan kepemilikan objek transaksi tersebut berpindah kepemilikan secara penuh dari penjual kepada pembeli. Artinya jika yang diberikan kepada pembeli hanyalah hak pakai, secara teoritis akad yang dipakai harusnya adalah akad sewa atau ijarah.

Perbedaan antara teori dan praktek ini mendorong penulis untuk meneliti lebih jauh tentang akad yang digunakan dalam transaksi kepemilikan rumah dengan sertifikat HGB tersebut. Adapun pokok permasalahan yang diteliti yaitu bagaimana praktek penjualan rumah dan tanah dengan status Hak Guna Bangunan di PT. Suci Griya Persada, serta bagaimana analisis hukum kontrak syariah terhadap praktek tersebut. Kedua permasalahan ini perlu untuk dianalisa secara detail, agar akad yang digunakan benar-benar sesuai dengan apa yang diinginkan dalam hukum kontrak syariah.

\section{Landasan Teori}

Hak Guna Bangunan adalah salah satu hak atas tanah yang diatur dalam Undang-Undang tentang Peraturan Dasar Pokok-Pokok Agraria, dimana dalam Pasal 35 peraturan tersebut disebutkan: ${ }^{5}$

\footnotetext{
${ }^{3}$ Adrian Sutedi, Peralihan Hak Atas Tanah dan Peralihannya (Jakarta: Sinar Grafika, 2010), 60-61.

${ }^{4}$ Urip Santoso, Hukum Agraria dan Hak-Hak. Atas Tanah (Jakarta: Kencana, 2009), 106.
}

(1).Hak Guna Bangunan adalah hak untuk mendirikan dan mempunyai bangunan atas tanah yang bukan miliknya sendiri, sehingga jangka waktu paling lama 30 tabun.

(2). Atas permintaan pemegang hak dengan mengingat keperluan serta keadaan bangunan-bangunannya, jangka waktu tersebut dalam ayat 1 dapat diperpanjang dengan waktu paling lama 20 tahun.

(3).Hak Guna Bangunan dapat beralih dan dialibkan.

Berdasarkan peraturan ini dapat diketahui bahwa yang dinamakan dengan HGB adalah hak untuk mendirikan dan mempunyai bangunan di atas tanah yang bukan miliknya sendiri dengan jangka waktu selama 30 tahun. Jadi, dalam hal ini pemilik bangunan berbeda dari pemilik hak atas tanah dimana bangunan tersebut didirikan. Artinya, pemegang HGB adalah orang yang berbeda dari pemegang Hak Milik atas bidang tanah dimana bangunan tersebut didirikan, atau dalam konotasi yang lebih umum, pemegang HGB bukanlah pemegang Hak Milik dari tanah dimana bangunan tersebut didirikan. Sehubungan HGB ini, Pasal 37 Undang-Undang Pokok Agraria menyatakan bahwa:

Hak Guna Bangunan terjadi :

a. Mengenai tanah yang dikuasai langsung oleh negara: karena penetapan pemerintah;

b. Mengenai tanah milik : karena perjanjian yang berbentuk autentik antara pemilik tanah yang bersangkutan dengan pibak yang akan memperoleh Hak Guna Bangunan itu, yang bermaksud menimbulkan bak tersebut.

Adapun pihak-pihak yang dapat terlibat dalam proses kepemilikan rumah dengan Sertifikat HGB antara lain yaitu:

1. Pihak pertama

Pihak pertama dalam hal ini adalah developer. Istilah Developer berasal dari bahasa asing yang menurut kamus bahasa inggris artinya adalah pembangun perumahan. ${ }^{6}$ Sedangkan menurut Pasal 5 ayat (1) Peraturan Menteri Dalam Negeri Nomor 5 Tahun 1974, disebutkan pengertian Perusahaan Pembangunan Perumahan, yaitu: "Perusahaan Pembangunan Perumahan adalah suatu perusahaan yang berusaha dalam bidang pembangunan perumahan dari berbagai jenis dalam jumlah yang besar di atas suatu kesatuan lingkungan pemukiman yang dilengkapi dengan prasarana-prasarana lingkungan dan fasilitas sosial yang diperlukan oleh masyarakat penghuninya."

${ }^{5}$ Kartini Muljadi dan Gunawan Widjaja, Hak-hak atas tanah (Jakarta: Kencana, 2004), 188.

${ }^{6}$ Hassan Sadily dan John Echlos, Kamus Inggris Indonesia (Jakarta: Gramedia, 1990). 
Developer pada dasarnya adalah pelaku usaha. Undang Undang Perlindungan Konsumen dalam Pasal 1 ayat (3) menyebutkan bahwa pengertian pelaku usaha adalah setiap orang perseorangan atau badan usaha, baik yang berkedudukan atau melakukan kegiatan dalam wilayah hukum Negara Republik Indonesia, baik sendiri maupun bersama-sama melalui perjanjian menyelenggarakan kegiatan usaha dalam bidang ekonomi."

Maka berdasarkan pengertian-pengertian di atas dapat disimpulkan bahwa developer itu adalah perusahaan yang bergerak dalam bidang pengadaan perumahan. Developer sendiri dapat dibagi 2 (dua) yakni developer perumahan bersubsidi dan developer perumahan biasa. Developer perumahan bersubsidi adalah developer yang menerima bantuan subsidi, artinya standar harga perumahan yang diberikan terjangkau, dan dikhususkan bagi masyarakat yang memiliki kelemahan dalam hal kemampuan ekonomi. ${ }^{7} \mathrm{Hal}$ ini dilakukan pemerintah agar dalam pelaksanaan pembangunan sosial dapat merata dan setiap strata kalangan masyarakat dapat menikmati dan berkesempatan memiliki tempat tinggal.

Developer di sini bertidak sebagai penjual rumah, yaitu sebagai suatu badan hukum atau perusahaan yang berkerja mengembangkan suatu kawasan pemukiman menjadi perumahan yang layak huni dan memiliki nilai ekonomis sehingga dapat dijual kepada masyarakat, ${ }^{8}$ yang dalam hal ini dilakukan oleh sebuah Perseroan Terbatas. Dalam penelitian ini saya ambil satu sampel Perseroan Terbatas (PT), yaitu PT. Suci Griya Perdana.

2. Pihak kedua

Pihak kedua dalam hal ini adalah pembeli. Pembeli merupakan seseorang yang membutuhkan rumah untuk memenuhi kebutuhannya. Baik itu sebagai kebutuhan dasar (Basic Need) atau hanya sebatas mencukupi kebutuhan sekunder, misalnya hanya sekedar untuk gaya hidup (Life Style).

3. Pihak ketiga

Pihak ketiga di sini adalah notaris.

Notaris merupakan pejabat publik yang menjalankan profesi dalam pelayanan hukum kepada masyarakat, guna memberi perlindungan

\footnotetext{
${ }^{7}$ Mohamad Heykal, "Analisis Tingkat Pemahaman KPR Syariah pada Bank Syariah di Indonesia: Studi Pendahuluan,” Binus Business Review 5, no. 2 (2014): 522. ${ }^{8}$ Sinta Wahyuni, "Analisis Pembelian Rumah Tunai dan Kredit (Studi Kasus Pada Perumahan Mutiara Hijau Tambaksogra PT. Graha Perwira Pratama, Kec.
}

dan jaminan hukum demi tercapainya kepastian hukum dalam masyarakat. Notaris juga merupakan satu-satunya pejabat umum yang berwenang untuk membuat akta otentik. Akta ini dapat menyangkut perbuatan, perjanjian dan penetapan yang diharuskan oleh suatu peraturan umum atau oleh yang berkepentingan dikehendaki untuk dinyatakan dalam suatu akta otentik. Notaris juga berwenang untuk menjamin kepastian tanggalnya, menyimpan aktanya, memberikan grosse, serta salinan dan kutipannya, semuanya sepanjang pembuatan akta itu oleh suatu peraturan umum tidak juga ditugaskan atau dikecualikan kepada pejabat atau orang lain. ${ }^{?}$

Pengertian ini sejalan dengan Peraturan Menteri Hukum dan Hak Asasi Manusia RI No. M.01HT.03.01 Tahun 2006, tentang Syarat dan Tata Cara Pengangkatan dan Pemindahan, dan Pemberhentian Notaris. Pasal 1 ayat (1) menyebutkan bahwa yang dimaksud dengan Notaris adalah pejabat umum yang berwenang untuk membuat akta otentik dan kewenangan lainnya, sebagaimana dimaksud dalam UndangUndang Jabatan Notaris.

Khusus dalam hal perpindahan HGB, notaris berperan sebagai saksi atas berlangsungnya transaksi kepemilikan rumah. Tugas notaris yaitu membuat pencatatan mengenai hal-hal yang berkenaan dengan proses akad kepemilikan rumah serta memberikan perlindungan secara hukum baik dari sisi penjual atau pembeli.

4. Pihak lain

Pihak lain yang dimaksudkan disini ialah penyalur dana, yang dalam hal ini diperankan oleh pihak Bank. Pihak ini akan ikut terlibat jika pembelian rumah itu dilakukan dengan cara kredit, sebab umumnya pembeli yang akan membeli rumah dengan cara kredit harus menjadi nasabah pada bank yang melakukan kerjasama dengan developer yang akan ia beli rumahnya.

Berdasarkan keterangan-keterangan di atas, maka dapat diambil poin inti bahwa Sertifikat HGB merupakan bentuk kepemilikan yang sifatnya sementara. Dikatakan sementara karena adanya batasan waktu tertentu, menjadikan kepemilikan tersebut terlihat atau tampak sementara.

Kembaran, Kab. Banyumas, Periode 2013/2014)" (IAIN Purwokerto, 2016), 2.

${ }^{9}$ Rahmad Hendra, "Tanggung Jawab Notaris terhadap Akta Otentik yang Penghadapnya Mempergunakan Identitas Palsu di Kota Pekanbaru," Jurnal Ilmu Hukum Riau 3, no. 01 (2011). 
Penggunaan sertifikat HGB ini tidak hanya berpengaruh kepada pihak pembeli semata, namun juga mempengaruhi tiga pihak lainnya yang dapat terlibat dalam proses kepemilikan rumah ini. Maka hasil analisa dalam pandangan hukum kontrak syariah, khususnya mengenai akad yang digunakan dalam proses transaksi tersebut, akan menjadi sangat vital bagi para pihak tersebut.

\section{Metode Penelitian}

Penelitian ini merupakan riset kualitatif yang menggunakan pendekatan Yuridis Sosiologis, yaitu suatu penelitian yang menekankan pada peraturan peraturan hukum yang berlaku. ${ }^{10}$ Adapun data primer dalam penelitian ini bersumber dari pengamatan secara langsung pada PT. Suci Griya Perdana melalui wawancara dengan pimpinan atau petugas bagian penerimaan untuk mendapatkan gambaran umum mengenai perusahaan, struktur organisasi, pembagian tugas dan tanggung jawab masing-masing karyawan, produk, proses kepemilikan rumah, serta akad yang digunakan. Data primer ini juga dikonfirmasi kembali melalui teknik triangulasi melalui observasi ke lapangan, khususnya kepada pembeli rumah selaku end user, serta dilengkapi pengamatan terhadap dokumendokumen seperti brosur, akta pendirian perseroan, dan akta jual-beli HGB antara penjual dan pembeli yang diterbitkan oleh notaris.

Data yang telah terkumpul selanjutnya dianalisa menggunakan perspektif hukum kontrak syariah, khususnya melalui teori jual-beli dan teori kepemilikan dalam hukum Islam. Kedua teori tersebut akan menjadi dasar qiyas sebagai bahan pembanding terhadap praktek penjualan rumah dengan tanah berstatus HGB yang merupakan kajian utama dalam riset ini.

\section{Data}

PT.Suci Griya Perdana merupakan sebuah badan usaha berjenis Perseroan Terbatas (PT) yang melayani jasa kepemilikan rumah dengan Sertifikat HGB. Kantor perusahaan menempati gedung yang beralamatkan di Jalan Guntung Harapan Rt.34 Rw.05 Kelurahan Guntung Manggis Kecamatan Landasan Ulin, Banjarbaru, Kalimantan Selatan. PT. Suci Griya Perdana dibentuk pada tanggal 27 Februari 2012 Pukul 12.30 WIB di hadapan Notaris Antoni Priagung Sarjana Hukum. PT. Suci Griya
Perdana sebelumnya berkedudukan di Kasongan, Kabupaten Katingan, Provinsi Kalimantan Tengah, yang kemudian berpindah ke Kota Banjarbaru, Kalimantan Selatan.

Pimpinannya yang menjabat sebagai Direktur pada awal pendirian adalah Edi Surawan. Beliau lahir di Banjarmasin pada tanggal 13 Mei 1993, dan bertempat tinggal di Banjarbaru, Jalan Golf Swargaloka, Rukun Tetangga 017 Rukun Warga 004, Kelurahan Landasan Ulin Utara, Kecamatan Liang Anggang, Propinsi Kalimantan Selatan. Selanjutnya yang menjabat sebagai Komisaris ialah Nurul Alfi, Lahir di Pangkoh, tanggal 01 Januari 1993, bertempat tinggal di Banjarbaru, Jalan Golf Swargaloka, Rukun Tetangga 017 Rukun Warga 004, Kelurahan Landasan Ulin Utara, Kecamatan Liang Anggang, Propinsi Kalimantan Selatan. ${ }^{11}$

Kedudukan Direktur di gantikan oleh Dewi Nawang Wulan pada awal tahun 2016. Beliau bertempat tinggal di Kota Banjarbaru, tepatnya di Perumahan Mahkota Griya Trikora. Awalnya beliau merupakan karyawan di PT. Dwi Putra Sulung, namun Perseroan ini sekarang menjadi mitra bisnis PT. Suci Griya Perdana. ${ }^{12}$

Produk perumahan yang ditawarkan pada PT.Suci Griya Perdana yaitu perumahan subsidi dengan tipe 36 standar, dengan fasilitas Jalan Induk 12 dan 10/9 Meter, jalan lingkungan 8 meter, listrik 900 watt, serta di lengkapi fasilitas umum, selain itu perumahan Suci Griya Perdana bekerjasama dengan Bank Tabungan Negara (BTN) untuk menerbitkan produk Kredit Perumahan Rakyat (KPR). KPR bersubsidi merupakan program pemerintah untuk membantu masyarakat agar bisa membeli rumah. KPR ini biasanya untuk masyarakat dengan pemasukan sekitar 3 dan 3,5 juta/bulan. KPR ini tertuang dalam skema yang dikenal dengan FLPP, yaitu Falisilitas Likuiditas Pembiayaan Perumahan. KPR subsidi sangat membantu masyarakat, terutama yang berada di golongan dengan pendapatan yang disyaratkan jenis ini. ${ }^{13}$

Uniknya, PT. Suci Griya Perdana ini menjual rumah yang tanahnya hanya berstatus HGB, bukan hak milik. Hal ini sebagaimana tercantum dalam potongan akta jual beli yang terlampir di bawah ini, dimana PT. Suci Griya Perdana selaku pihak pertama "menjual" HGB atas sebidang tanah seluas $180 \mathrm{~m}^{2}$ kepada pihak kedua.

\footnotetext{
${ }^{10}$ Bambang Sunggono, Metode Penelitian Hukum (Jakarta: Raja Grafindo Persada, 2007), 75.

${ }^{11}$ Data ini diolah dari Akta Pendirian Perseroan Terbatas PT. Suci Griya Perdana
}

12 Yuni Murieyati, Accounting dan Admin, Wawancaran di PT. Suci Griya Perdana, pada tanggal 29 Mei 2016

13 Silvia Anggraini, Costumer Service, Wawancara di PT.Suci Griya Perdana, pada tanggal 23 Juli 2016 
PEJABAT PEMBUAT AKTA TANAH

(PPAT)
NOOR HASANAH, S.H.

NOOR HASANAH, S.H.
DAERAH KER.IA KOTA BAN.IARBARU

SK Menteri Negara Agrana Kepala Badan Pertanahan Nasional

Nomor: 3 X1 1000 Tanggal o. Maret 1090

Jalan Ahmad Yani $\mathrm{km}, 3,3,7 \mathrm{No}, 7$ Trlp $(0511) 477242$.

Fax. $(0511) 4780990$ Banarbaru - halimantan Selatan

AKTA JUAL BELI
Nomor. $465 / 2015$
Lembar Pertama/ Kedua
Pada hari ini, hari Kamis, tanggal 19 (sembilanbelas) bulan Maret

hari Kamis,

tahun 2015 (duaribu limabelas)

Hadir dihadapan saya NOOR HASANAH, Sarjana Hukum vang berdasarkan Surat Keputusan Menteri Negara Agraria/Kepala Badan Pertanahan Nasional Nomor : 3-X1-1996 tanggal 04 (empat) Maret 1996 (seribu sembilanratus sembilanpuluh enam) diangkat/ditunjuk scbagai Pcjabat Pembuat Akta Tanah, yang ....... selanjutnya disebut PPAT, yang dimaksud dalam Pasal 7 Peraturan Pemerintah Nomor 24 Tahun 1997 tentang Pendaftaran Tanah, ..... dengan daerah kerja kota Banjarbaru dan berkantor di Jalan Ahmad Yani Kilometer 33,7 Nomor 7 Banjarbaru, dengan dihadiri oleh saksi saksi yang saya kenal dan akan disebut pada bagian akhir akta ini

1. Tuan EDI SURAWAN, Lahir di Banjarmasin, pada tanggal . 13 (tigabelas) Mei 1993 (seribu sembilanratus sembilanpuluh ..... tiga), Warga Negara Indonesia, Karyawan Swasta, bertempat ....... tinggal di Banjarbaru. Jalan Golf Swargaloka, Rukun Tetangga . 017, Rukun Warga 004, Kelurahan Landasan Ulin Utara, Kecamatan Liang Anggang, pemegang Kartu Tanda Penduduk .... dengan Nomor Induk Kependudukan (NIK) : 6372041305930004. yang berlaku sampai dengan tanggal 13 (tigabelas) Mei $2015 \ldots$ (duaribu limabelas) :

-menurut keterangannya dalam hal ini bertindak dalam .......

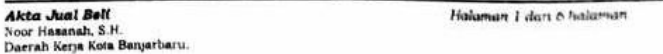

sebidang tanah sebagaimana diuraikan dalam Surat Ukur ........ tanggal 06 (enam) Pebruart 2014 (duaribu empatbelas), Nomor 4913/GM/2014, seluas $180 \mathrm{M}^{2}$ (seratus delapanpuluh ........... meter persegi), dengan Nomor Identifikasi .

Bidang Tanah (NIB) : 17.11.72.06.14465 dan Surat …............ Pemberitahuan Pajak Terhutang Pajak Bumi dan Bangunan .......

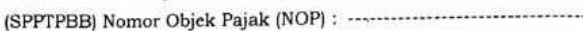
63.72.010.006.012-1123.0.

Adapun penggunaan dan pemanfaatan tanah adalah untuk ....... perumahan.

Jual beli ini meliputi pula segala sesuatu yang sekarang ada -.......... maupun yang dikemudian hari berdiri, tertanam/terdapat diatas .... tanah hak tersebut yang menurut sifat dan peruntukkannya atau ... menurut Undang-Undang dapat dianggap sebagai benda -.............. tetap/tidak bergerak, tanpa kecuali.

Selanjutnya semua yang diuraikan diatas dalam akta ini disebut .... Obyek Jual Beli".

Pihak Pertama dan Pihak Kedua menerangkan bahwa : .................

a. Jual beli ini dilakukan dengan harga $\mathbf{R p}$. $\mathbf{9 5 . 0 0 0 . 0 0 0 , 0 0 ~ . . . . . . . . . ~}$ (sembilanpuluh lima juta rupiah).

b. Pihak Pertama mengaku telah menerima sepenuhnya uang ...... tersebut diatas dari Pihak Kedua dan untuk penerimaan uang tersebut akta ini berlaku pula sebagai tanda penerimaan yang sah ( kwitansi).

c. Jual beli ini dilakukan dengan syarat-syarat sebagai berikut : ... . Pasal 1

Mulai hari ini obyek jual beli yang diuraikan dalam akta ini telah--... menjadi milik Pihak Kedua dan karenanya segala keuntungan yang-didapat dari, dan segala kerugian/beban atas obyek jual beli ........... tersebut di atas menjadi hak/beban Pihak Kedua. ...........................

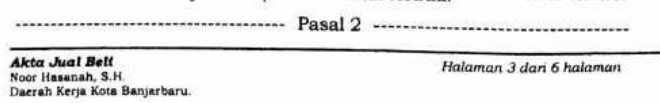

Praktek ini berbeda dengan transaksi jual beli rumah yang pada umumnya disertai pula dengan pemindahan hak milik tanah. Implikasi hukumnya menjalani jabatannya selaku DIREKTUR dari dan oleh karena itu untuk dan atas nama Perseroan Terbatas PT. SUCI GRIYA PERDANA berkedudukan di Kasongan, yang Anggaran ........ Dasarnya dimuat dalam Akta Pendirian Perseroan Terbatas PT. SUCI GRIYA PERDANA, bertanggal 27 (duapuluh tujuh) Pebruari 2012 (duaribu duabelas), Nomor 81, yang dibuat .... dihadapan ANTONI PRIAGUNG, Sarjana Hukum, Notaris di Kabupaten Katingan :

-Anggaran Dasar mana telah memperoleh pengesahan dari ... Menteri Hukum Dan Hak Asasi Manusia Republik Indonesia melalui Surat Keputusannya bertanggal 07 (tujuh) Mei 2012 (duaribu duabelas) Nomor :

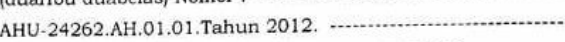
Selaku Penjual, selanjutnya disebut PIHAK PERTAMA

2. Tuan FRANSISKUS TAEK, Lahir di Kampung Pegawai Basi, ..... pada tanggal 15 (limabelas) Juni 1981 (seribu sembilanratus -... delapanpuluh satu), Warga Negara Indonesia, Karyawan Swasta, bertempat tinggal di Kota Balikpapan, Jalan Marsma R. .......... Iswahyudi Nomor 478, Rukun Tetangga 026, Kelurahan ............ Sepinggan, Kecamatan Balikpapan Selatan, pemegang Kartu ..... Tanda Penduduk dengan Nomor Induk Kependudukan (NIK) : .... 6471051506810011, yang berlaku sampai dengan tanggal ........

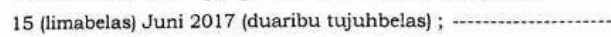
-untuk sementara waktu berada di Banjarbaru. Selaku Pembeli, selanjutnya disebut PIHAK KEDUA.

Penghadap Pihak Pertama saya, PPAT kenal yang lainnya ............... diperkenalkan olehnya kepada saya, PPAT

Pihak Pertama menerangkan dengan ini menjual kepada Pihak ....... Kedua dan Pihak Kedua menerangkan dengan ini membeli dari Pihak Pertama :

- Hak Guna Bangunan Nomor : 1029/Guntung Manggis, atas -.-.

Akta Shal Belt
Noor Hasanah. S.H.
Deerth Kerfja Kota Bapjarbaru.

Pihak Pertama menjamin, bahwa obyek jual beli tersebut di atas ..... tidak tersangkut dalam suatu sengketa, bebas dari sitaan, tidak ..... terikat sebagai jaminan untuk sesuatu utang yang tidak tercatat .... dalam sertipikat, dan bebas dari beban-beban lainnya yang berupa -

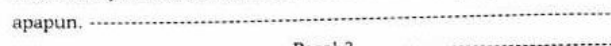
Pihak Kedua dengan ini menyatakan bahwa dengan jual beli ini ...... kepemilikan tanahnya tidak melebihi ketentuan maksimum ............ penguasaan tanah menurut ketentuan perundang-undangan yang --

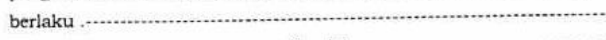

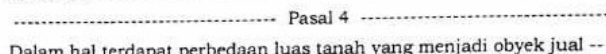
beli dalam akta ini dengan hasil pengukuran oleh instansi Badan .... Pertanahan Nasional, maka para pihak akan menerima hasil ......... pengukuran instansi Badan Pertanahan Nasional tersebut dengan ... tidak memperhitungkan kembali harga jual beli dan tidak akan .......

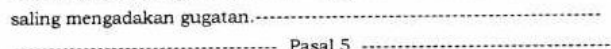

a. Para pihak dengan ini menyatakan bahwa Identitas dari para -... pihak adalah benar adanya sesuai dengan data yang diberikan ... kepada saya, PPAT, jika dikemudian hari ternyata hal tersebut .... tidak benar dan timbul tuntutan hukum maka semuanya itu ..... menjadi tanggung jawab para pihak.-.

b. Para pihak dengan ini menyatakan telah saling mengetahui ........ terhadap letak dan batas-batas tanah yang menjadi obyek jual ... beli dalam akta ini, dan untuk itu para pihak tidak akan saling -mengadakan gugatan.

c. Pihak Pertama menjamin bahwa apa yang dijual dalam akta ini -. tidak ada pihak lain yang turut mempunyai hak atas tanah ....... tersebut dan karenanya segala tuntutan/gugatan dari siapapun juga karena hak pihak lain yang dimaksud, maka jika ada adalah

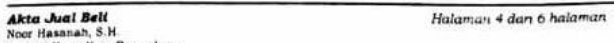

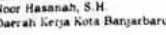

pun tentu akan menjadi berbeda, karena tanah dengan status HGB pada hakikatnya bukanlah milik dari pemegang HGB tersebut. Artinya ketika negara 
ataupun pemegang hak milik atas tanah tersebut meminta kembali tanahnya sesuai dengan jangka waktu yang ditentukan, maka pemegang HGB harus merelakan tanah berikut bangunan rumah yang ada di atasnya terkecuali ada ganti rugi dari pemilik asli tanah.

Selanjutnya penulis juga melakukan survey dalam bentuk wawancara kepada nasabah yang melakukan proses transaksi kepemilikan rumah dengan tanah bersertifikat HGB di PT. Suci Griya Perdana. Setelah diadakannya wawancara terdapat ketidaksesuaian antara keterangan dari developer dengan nasabah. Developer menyatakan bahwa ketika proses akad, pihak dari developer telah menjelaskan kepada nasabah mengenai status sertifikat rumah yang dibelinya, bahwasanya rumah tersebut sertifikat tanahnya berstatus HGB. Sayangnya, setelah dilakukan survey kepada nasabah, banyak diantara mereka mengatakan bahwa sertifikat mereka berupa sertifikat Hak Milik, dan mereka mengatakan tidak ada keharusan untuk melakukan perpanjangan.

\section{Analisis}

Berdasarkan data penelitian yang telah dikumpulkan oleh penulis terkait dengan akad transaksi kepemilikan rumah dengan sertifikat Hak Guna Bangunan (HGB) terdapat ketidakselarasan antara akad yang digunakan dengan proses kepemilikan rumah tesebut. Pada uraian sebelumnya, penulis telah menjelaskan mengenai proses kepemilikan rumah dengan sertifikat HGB di PT. Suci Griya Perdana dimana mereka menggunakan akad jual beli dalam transaksi tersebut, namun ketika dipelajari secara lanjut oleh penulis, proses kepemilikan cenderung bukan termasuk akad jual beli.

Akad kepemilikan rumah dengan sertifikat HGB yang dilakukan di PT Suci Griya Perdana tersebut sekilas tampaknya tidak sesuai jika disebut jual beli. Hal ini dikarenakan syarat kepemilikan dari jual beli tidak dipenuhi. Jual beli dikategorikan kepada kepemilikan sempurna dan salah satu syarat dari kepemilikan sempurna adalah tidak adanya batasan waktu kepemilikan tersebut. Hal ini sebagaimana yang telah ditulis oleh Mardani dalam bukunya yang berjudul "Fiqh Ekonomi Syariah". Beliau menyebutkan dalam buku ini mengenai syarat dari kepemilikan tidak sempurna (milk alnaqis), yaitu adanya batasan waktu, yang dalam hal

14 Mardani, Fiqh Ekonomi Syariah (Jakarta: Kencana, 2012), 68.

15 A. Djazuli, Kaidah-Kaidah Figh, Kaidah-Kaidah Hukum Islam dalam Menyelesaikan Masalab-masalah yang Praktis (Jakarta: Kencana, 2006), 134-35. ini apabila seseorang hanya menguasai materi harta itu, tetapi manfaatnya di kuasai orang lain, seperti sawah seseorang yang pemanfaatannya diserahkan kepada orang lain melalui wakaf, atau rumah yang pemanfaatannya dikuasai orang lain. Akad yang digunakan dalam peralihan kepemilikan tidak sempurna ini ada dua, yaitu sewa-menyewa dan pinjam meminjam. ${ }^{14}$

Selaras dengan pendapat tersebut, H. A. Djazuli dalam bukunya tentang kaidah-kaidah fiqh, menjelaskan mengenai akad mu'awadhah. Akad mu'awadhah adalah akad yang dilakukan oleh dua pihak yang masing-masing memiliki hak dan kewajiban, seperti jual beli. Satu pihak (penjual) berkewajiban menyerahkan barang yang berhak terhadap harga barang, dan pihak lain yaitu pembeli berkewajiban menyerahkan harga barang dan berhak terhadap barang yang dibelinya. Akad seperti ini tidak sah apabila dibatasi waktunya. Apabila waktunya dibatasi, maka bukan termasuk akad jual beli, melainkan menjadi akad sewa menyewa. ${ }^{15}$

Maka dari kedua pendapat di atas, dapat dipahami bahwa pemindahan kepemilikan sementara sebagaimana yang dipraktekkan oleh PT. Suci Griya Persada yang menjual tanahnya dengan sertifikat HGB, harus dilakukan dengan akad sewa menyewa atau pinjam meminjam, bukan akad jual beli.

Selanjutnya mengenai pembatasan waktu pada sertifikat HGB, penulis cenderung sepakat kepada pendapat Ridwan dalam buku beliau yang berjudul "Pemilikan Rakyat dan Negara atas Tanah Menurut Hukum Pertanahan Indonesia dalam Perspektif Hukum Islam". Beliau menyebutkan bahwa dalam hukum Islam dikenal konsep kedaluarsa dalam hal kepemilikan tanah terlantar. Ketentuan hukumnya adalah jika tanah yang telah dibuka tidak dikelola secara layak dalam kurun waktu tiga tahun, maka hak kepemilikannya bisa dicabut dan kembali menjadi hak milik negara, dan ini adalah pendapat yang disepakati oleh para ulama fiqh. Kebijakan kedaluarsa atas kepemilikan tanah yang ditelantarkan pada zaman Rasulullah ini kemudian dilanjutkan pada masa kekhalifahan Umar bin Khatab. Menurut Umar, pemilik lahan yang tidak mengelola lahannya selama tiga tahun, maka telah merugikan kepentingan masyarakat luas, dan orang tersebut telah melakukan kedhaliman secara sosial. ${ }^{16}$

\footnotetext{
${ }^{16}$ Ridwan, Pemilikan Rakyat dan Negara atas Tanah Menurut Hukum Pertanahan Indonesia dalam Perspektif Hukum Islam (Jakarta: Badan Litbang dan Diklat, Kementerian Agama RI, 2010), 314.
} 
Para ulama Fiqh berbeda pendapat dalam hal jangka waktu penguasaan hak milik tanah. Ada ulama yang berpendapat jangka waktu kepemilikan itu 33 tahun, sebagian lagi berpendapat 30 tahun. Pendapat yang banyak diikuti adalah 33 tahun. UUPA sendiri mengatur tentang hak-hak atas tanah yang berjangka waktu tertentu seperti Hak Guna Usaha (HGU) dan HGB, yaitu bahwa dengan berakhirnya jangka waktu yang bersangkutan, haknya menjadi hapus, jika tidak dimintakan perpanjangan waktu. Pasal 29 UUPA menyebutkan bahwa jangka waktu Hak Guna Usaha ataupun Hak Pakai adalah paling lama 25 tahun, sedangkan HGB dalam Pasal 35 dinyatakan bahwa jangka waktunya paling lama 30 tahun dan dapat diperpanjang paling lama 20 tahun. Ketentuan pembatasan jangka waktu oleh pemerintah mengindikasikan bahwa negara berhak untuk melakukan intervensi dalam hal pemanfaatannya.

Menurut Muhammad Faruq al-Nabahany, hukum pencabutan hak milik itu hukumnya relatif tergantung pada siapa yang melakukannya dan atas alasan apa pencabutan hak itu dilakukan. Menurutnya, pencabutan hak milik itu kemungkinan hukumnya ada tiga, yaitu sebagai berikut:

1. Pencabutan hak milik individu oleh negara atas dasar kepentingan para penguasa negara yang otoriter dengan tujuan untuk memperkaya penguasaannya, maka hukumnya haram dan termasuk perbuatan aniaya atau kezaliman.

2. Pencabutan hak milik oleh negara dengan tujuan untuk menciptakan kemaslahatan masyarakat yang mendesak seperti pencabutan hak milik untuk kepentingan pembangunan fasilitasfasilitas umum seperti perluasan jalan umum, dan mendirikan rumah sakit, maka tidak diragukan lagi hukumnya boleh. Hanya saja sebelum keputusan pencabutan hak milik individu dilakukan, harus dipastikan derajat kemaslahatannya terlebih dahulu, untuk menghindari terjadinya tindakan yang tidak adil. Bahkan wajib hukumnya bagi negara untuk memberi kompensasi berupa ganti rugi yang layak kepada para pemilik tanah.

3. Pencabutan hak milik oleh negara terhadap semua aset/harta seseorang yang diperoleh dengan cara yang melanggar hukum baik melanggar hukum syara' maupun undangundang. Termasuk dalam kategori harta yang cara perolehannya melanggar hukum adalah harta yang diperoleh melalui praktek bisnis yang mengandung unsur ribawi, penimbunan barang atau harta benda hasil dari korupsi. Hukum pencabutan hak milik ini oleh negara dibenarkan dengan tujuan untu menghindari kerugian oleh masyarakat luas.

Berdasarkan keterangan ini, penulis menyimpulkan bahwa kepemilikan terhadap tanah, baik berbentuk sertifikat Hak Milik, apalagi sertifikat HGB, bisa diambil alih oleh pemerintah jika tanah atau rumah tersebut ditelantarkan dan/atau karena adanya kemaslahatan umum yang lebih penting. Namun jika pemilik tidak menelantarkannya dan juga tidak adanya mudharat bagi kehidupan bersama, maka pemerintah tidak diperkenankan untuk mencabut hak tersebut. Artinya, pembatasan waktu pemanfaatan tanah sebagaimana yang ada dalam tanah bersertifikat HGB sebenarnya boleh-boleh saja dan sama sekali tidak dipermasalahkan dalam hukum kontrak syariah.

Maka berdasarkan perspektif hukum kontrak syariah, bentuk transaksi penjualan rumah dengan tanah bersertifikat HGB tersebut tidak diperkenankan jika mekanismenya dilakukan sepenuhnya dengan akad jual beli. Beda halnya jika developer selaku penjual menjualnya secara terpisah, yaitu rumah dengan akad jual beli dan tanah dengan akad sewa, maka transaksi tersebut dapat dibenarkan.

\section{Kesimpulan}

1. PT. Suci Griya Perdana melakukan penjualan rumah dengan tanah bersertifikat HGB diantaranya melalui skema KPR dengan bekerjasama kepada perbankan. Uniknya, walaupun tanahnya hanya bersertifikat HGB, namun akad yang digunakan adalah akad jual beli yang dibuktikan dengan akta jual beli yang ditandatangani para pihak di bawah pengawasan notaris.

2. Berdasarkan analisis hukum kontrak syariah, khususnya yang bersumber dari pendapat cendekiawan muslim kontemporer, tanah bersertifikat HGB hanya bisa dialihtangankan menggunakan akad ijarah. Hal ini dikarenakan sifat yang melekat pada sertifikat HGB tersebut yang hanya merupakan hak pakai, bukan hak milik. Maka disarankan kepada pihak-pihak yang melakukan penjualan rumah dengan tanah bersertifikat HBG ini menggunakan akad sewa dalam transaksi tanahnya, serta memberikan keterangan sejelas-jelasnya kepada pembeli agar tidak ada ketidaksepahaman terhadap status tanah tersebut.

\section{Daftar Pustaka}

A. Djazuli. Kaidah-Kaidah Fiqh, Kaidah-Kaidah Hukum Islam dalam Menyelesaikan Masalah- 
masalah yang Praktis. Jakarta: Kencana, 2006.

Adrian Sutedi. Peraliban Hak Atas Tanah dan Peralihannya. Jakarta: Sinar Grafika, 2010.

Bambang Sunggono. Metode Penelitian Hukum. Jakarta: Raja Grafindo Persada, 2007.

Hassan Sadily, dan John Echlos. Kamus Inggris Indonesia. Jakarta: Gramedia, 1990.

Hendra, Rahmad. "Tanggung Jawab Notaris terhadap Akta Otentik yang Penghadapnya Mempergunakan Identitas Palsu di Kota Pekanbaru." Jurnal Ilmu Hukum Riau 3, no. 01 (2011).

Heykal, Mohamad. "Analisis Tingkat Pemahaman KPR Syariah pada Bank Syariah di Indonesia: Studi Pendahuluan." Binus Business Review 5, no. 2 (2014).

Listyorini, Sari. "Analisis Faktor-Faktor Gaya Hidup dan Pengaruhnya Terhadap Pembelian Rumah Sehat Sederhana (Studi pada Pelanggan Perumahan Puri Dinar Mas PT. Ajisaka di Semarang)." Jurnal Administrasi Bisnis 1, no. 1 (2012).
Mardani. Fiqh Ekonomi Syariah. Jakarta: Kencana, 2012.

Muhaimin, Toha. "Mengukur Kualitas Hidup Anak." Kesmas: National Public Health Journal 5, no. 2 (2010): 51-55.

Muljadi, Kartini, dan Gunawan Widjaja. Hak-bak atas tanah. Jakarta: Kencana, 2004.

Ridwan. Pemilikan Rakyat dan Negara atas Tanah Menurut Hukum Pertanahan Indonesia dalam Perspektif Hukum Islam. Jakarta: Badan Litbang dan Diklat, Kementerian Agama RI, 2010.

Urip Santoso. Hukum Agraria dan Hak-Hak Atas Tanah. Jakarta: Kencana, 2009.

Wahyuni, Sinta. "Analisis Pembelian Rumah Tunai dan Kredit (Studi Kasus Pada Perumahan Mutiara Hijau Tambaksogra PT. Graha Perwira Pratama, Kec. Kembaran, Kab. Banyumas, Periode 2013/2014)." IAIN Purwokerto, 2016. 